\title{
Selective Distribution of the 57 kDa Neural Intermediate Filament Protein in the Rat CNS
}

\author{
Betty Ann Brody, ${ }^{1,2}$ Catherine A. Ley, ${ }^{2, a}$ and Linda M. Parysek ${ }^{3, a}$ \\ Departments of 'Pathology, ${ }^{2}$ Neurology, and ${ }^{3}$ Cell Biology and Anatomy, Northwestern University Medical School, \\ Chicago, llinois 60611
}

In order to determine the CNS distribution of the $57 \mathrm{kDa}$ neural intermediate filament protein (NIFP), a specific antiserum was used in immunofluorescence studies on serial sections taken from each spinal cord level and at $300-\mu \mathrm{m}$ intervals through the rat brain. The labeling pattern was recorded onto camera lucida tracings of adjacent sectlons stained with hematoxylin and eosin/luxol fast blue. Three major immunolocalization patterns were revealed. (1) Both large-caliber and fine-caliber axons of optic and all brain stem cranial nerves and their tracts except for the auditory portion of the VIIIth nerve. (2) An extensive array of finecaliber fibers in the cerebellar white matter and brain stem with region-specific variation in pattern and density. Prominent among the regions with dense arrays of labeled processes were selective cerebellar afferent systems, particularly olivocerebellar fibers, visual afferents arising in the retina, and selective regions of reticular formation. In contrast to the brain stem, the telencephalon contained rare label. (3) Filamentous labeling of neuronal cytokarya in sensory ganglia and a small number of CNS nuclear groups, including all autonomic nuclei and the cholinergic pontine nuclei. On sections of selected CNS regions, distribution patterns of the $57 \mathrm{kDa}$ NIFP were correlated to results obtained by in situ hybridization of a cDNA probe for the 57 kDa NIFP. The data suggest the possible existence of neuronal IF proteins specifically related to selective anatomic and/or neurotransmitter systems.

Intermediate filaments (IF) are prominent and ubiquitous components of eukaryotic cells. These filaments are composed of one or more members of a family of fibrous proteins that have a conserved $\alpha$-helical core region and variable end domains. Variation of the size and amino acid sequences within the $\alpha$-helical core domain indicates a division of the IF family into 5 types (Steinert and Roop, 1988). Type IV IF are composed of a triplet of proteins that are restricted to the nervous system and thought to be present in most CNS neuronal cell bodies and axons (Shaw et al., 1981; Trojanowski et al., 1986). Al-

\footnotetext{
Received July 7, 1988; revised Nov. 23, 1988; accepted Dec. 19, 1988.

This work was supported by the Les Turner Amyotrophic Lateral Sclerosis (ALS) Foundation and the Boothroyd Foundation. L.M.P. is a fellow of the Les Turner ALS Foundation.

Correspondence should be addressed to Betty Ann Brody, M.D., Ph.D., Department of Pathology, P-232, Northwestern Memorial Hospital, 303 East Superior St., Chicago, IL 60611 .

a Present address: Department of Anatomy and Cell Biology, University of Cincinnati, 231 Bethesda Ave., ML 521, Cincinnati, OH 45267.

Copyright (C) 1989 Society for Neuroscience $0270-6474 / 89 / 072391-11 \$ 02.00 / 0$
}

though polyacrylamide gel electrophoresis of neuronal IF preparations from various areas of the nervous system has consistently illustrated the triplet proteins $(200,150,68 \mathrm{kDa})$ to be major components, other bands, often in the 55-60 kDa range, have been noted (Liem et al., 1978; Schlaepfer and Freeman, 1978; Czosnek and Soifer, 1980; Brown et al., 1981; Yen and Fields, 1981; Zackroff et al., 1982).

An IF protein of $56-57 \mathrm{kDa}$ has been identified as one of the major IF polypeptides present in both the neuron-like cell line PC12 and in neuroblastoma cell lines (Portier et al., 1982, 1984a, b; Parysek and Goldman, 1987). Immunolocalization studies have shown that the $56 \mathrm{kDa}$ IF protein, peripherin (Escurat et al., 1988), and the $57 \mathrm{kDa}$ neural intermediate filament protein (NIFP; Parysek and Goldman, 1988) are localized exclusively in ncuronal clements of rat tissucs. In situ hybridization showed that the $57 \mathrm{kDa}$ NIFP mRNA was detectable in areas of the nervous system that labeled with $57 \mathrm{kDa}$ NIFP antiserum (Parysek et al., 1988). In another laboratory, a cDNA clone (clone 73) representing a message that increased markedly during nerve growth factor stimulated PC12 cell differentiation (Leonard et al., 1988) was found to encode an IF protein. In situ hybridization using RNA transcripts of portions of clone 73 indicated that message is present in peripheral nervous system (PNS), sensory ganglia, and a subset of spinal cord and brain stem nuclei (Leonard et al., 1988). A portion of the sequence reported for clone 73 is identical to that of the cDNA for the $57 \mathrm{kDa}$ NIFP (Parysek et al., 1988). The predicted amino acid sequence of the $57 \mathrm{kDa}$ NIFP cDNA indicates that it is a type III IF protein as are vimentin, desmin, and GFAP. Thus, these recent studies (Leonard et al., 1988; Parysek and Goldman, 1988; Parysek et al., 1988) indicatc that a type III IF protein is present in mature neurons and, furthermore, that it has a restricted distribution in comparison to the type IV neurofilament triplet (NFT) proteins. In this study, we have examined the distribution of the $57 \mathrm{kDa}$ NIFP in the rat CNS using fluorescence-immunolocalization methods. This work complements studies on the distribution of the mRNA for this protein. An analysis of the complete, unique anatomic distribution of the $57 \mathrm{kDa}$ NIFP in both neuronal cell bodies and axonal processes of the CNS has illuminated systems-specific labeling patterns.

\section{Materials and Methods}

Tissue preparation. The brains of albino rats were removed without fixation immediately following sacrifice of the animals and were sliced in the coronal plane into $3-\mathrm{mm}$ blocks utilizing a measured rat brain cradle (Zivic-Miller). Blocks of cervical, thoracic, lumbar, and sacral cord were taken in the transverse plane. All blocks were embedded in $7.0 \%$ gelatin, oriented in flat cryomolds (Tissue-Tek), and frozen in dry 
ice-cooled ethanol. Ten serial 4-5 $\mu \mathrm{m}$ sections (forming a serial set) were taken from each brain block every 60 sections until the block was exhausted. One set of serial sections was taken from each spinal cord block. Sections were air-dried and stored in desiccated boxes at $-40^{\circ} \mathrm{C}$. The first slide of each series was stained with hematoxylin and eosin/ luxol fast blue (H\&E/LFB) (Luna, 1968). Adjacent slides were immunolabeled and other slides in the same series were processed for in situ hybridization.

Immunofluorescence. $57 \mathrm{kDa}$ NIFP antiserum production was initiated by injection of an emulsified mixture of Freund's adjuvant and approximatley $1 \mathrm{mg}$ of $57 \mathrm{kDa}$ NIFP in a polyacrylamide gel slice. After 3 weeks, a booster injection of half of the original amount of antigen without adjuvant was given. Bleed one was drawn 7 d later; serum from only one (199) of the 2 rabbits produced a reaction to the antigen as assayed by immunoblot. Serum from bleed 2 of the antibody-producing rabbit, diluted 1:50 in Tris-saline, $\mathrm{pH} 8.2,0.1 \% \mathrm{BSA}$ added, was used for this study.

Immunolabeling with $57 \mathrm{kDa}$ NIFP antiserum or the monoclonal antibody (15G1) that cross-reacts with the $200 \mathrm{kDa}$ and $150 \mathrm{kDa}$ NFT proteins (Parysek and Goldman, 1987) was carried out as described previously (Parysek and Goldman, 1988). One slide from alternate or, in some cases, every serial set was incubated sequentially with normal goat serum, $57 \mathrm{kDa}$ NIFP antiserum, and fluoresceinated goat antirabbit IgG (Kirkegaard and Perry). Sections from the midbrain, pons, and medulla were double-labeled with $57 \mathrm{kDa}$ NIFP antiserum and $15 \mathrm{G} 1$ followed by a mixture of fluorescein-labeled goat anti-rabbit IgG and rhodamine-labeled goat anti-mouse $\mathrm{IgG}$. The fluorescein- and rhodamine-labeled secondary antibodies showed no cross-reaction with mouse and rabbit $\operatorname{IgG}$, respectively.

Processing of CNS sections with preimmune serum from rabbit 199 showed no labeling of structures that contained the $57 \mathrm{kDa}$ NIFP. Other control slides in which serum was omitted from the labeling procedure showed identical results.

Immunoblot analyses indicate that the reaction of $15 \mathrm{G} 1$ in whole brain or whole spinal cord tissue is restricted to the $150 \mathrm{kDa}$ and 200 $\mathrm{kDa}$ neural IF proteins and does not include reaction with any other NIFP or other phosphorylated proteins.

In situ hybridization. In situ hybridization was carried out on brain stem sections at the level of the V, VII, and XII cranial nerve nuclei. The procedure utilized ${ }^{35} \mathrm{~S}$-labeled RNA transcripts of a cDNA that encodes three-quarters of coil 2 of the rod domain and the entire carboxyl terminus of the $57 \mathrm{kDa}$ NIFP. Characterization of the cDNA (designated clone 199E) and in situ labeling methods were described previously (Parysek et al., 1988).

Section analysis. The stereotaxic coordinates of each H\&E/LFB stained section were correlated to the plates of a stereotaxic rat brain atlas (Paxinos and Watson, 1986), and specific anatomic regions were identifed by comparison to their positions in the atlas. Sections were examined on a Zeiss Axioskop, and the labeling patterns were recorded onto camera lucida tracings of the adjacent H\&E/LFB-stained sections. The presence of vessels, leptomeninges, and neurons, identified by phase or dark-field optics, allowed for accurate placement of labeled structures onto the tracings.

\section{Results}

Immunolabeled brain and spinal cord sections revealed the presence of $57 \mathrm{kDa}$ NIFP both in the cytokarya of select neuronal groups and in neuronal processes of varying sizes (Fig. 1).

The cytokarya of most neurons in the CNS were $57 \mathrm{kDa}$ NIFP antiserum-negative. In a few specific nuclei, however, clusters of neurons having a bright fibrillar pattern of fluorescence were consistently present in all relevant coronal sections (Table 1). These nuclei include the caudal magnocellular hypothalamic group; the autonomic motor nuclei, i.e., the intermediolateral nucleus of the spinal cord, the dorsal vagus, ambiguous, and Edinger-Westphal nuclei, and a group of lateral pontine neurons possibly representing salivatory neurons; the $\beta$-subnucleus of the inferior olive; and the paragenual nucleus. In addition, a subset of cells in sensory ganglia, including the dorsal root ganglion, mesencephalic ganglion, and trigeminal ganglion, contained the $57 \mathrm{kDa}$ NIFP; retinal ganglion cells also were labeled.
No label was identified in olfactory receptor neurons within olfactory epithelium. Fibrillar labeling was also present in numerous neurons scattered throughout the region of the peripeduncular tegmental nucleus (PPTg) and the lateral dorsal tegmental nucleus (LDTg) in the upper pons. In contrast, rare labeled neurons were present in layers III and V of the cerebral cortex without apparent regional predilection (Fig. 2).

Immunoreactive neurons were identified rarely among the motor neurons of the V and VII cranial nerve nuclei (less than $1 /$ section) and somewhat more frequently among motor neurons in the oculomotor nucleus and the ventral horn of the spinal cord (1-3/section). The axons of the motor outflow were labeled, and the motor nuclei often contained short segments of these axons apparently arising from unlabeled cytokarya. In order to determine whether mRNA for the $57 \mathrm{kDa}$ NIFP was present in these unlabeled cytokarya, in situ hybridization was performed. ${ }^{35}$ S-labeled antisense RNA transcripts of the cDNA labeled the cytokarya of the V, VII, and XII cranial nerve nuclei (Fig. 3), the dorsal vagus, and the nucleus ambiguous, as well as several inferior olive (IO) subnuclei. In the sections examined, in situ hybridization revealed no label in cytokarya in the cerebellum or in other nuclear regions of the brain stem.

Immunolabeling also revealed a unique restricted distribution of the $57 \mathrm{kDA}$ NIFP in CNS axons (Table 2). Except for the auditory and olfactory nerves, all spinal nerve roots and cranial nerves as well as their intraparenchymal tracts were labeled. The intensity of axonal labeling was uniform for all axons of motor nerves (Fig. $4 A$ ) as well as sensory components of VII, IX, and X. In contrast, somatosensory nerves and tracts (the dorsal roots and columns and the 5th cranial nerve and tracts) and the optic nerve and tract contained at least 2 populations of axons of small and large caliber with different labeling characteristics (Fig. 4B). In these nerves and tracts, small-caliber axons labeled intensely. The label of the adjacent large-caliber axons, however, was not as intense as that of the small-caliber axons or large-caliber axons of other cranial nerves. Labeled processes of primary sensory neurons could be detected in otherwise unlabeled regions of the respective second-order nuclei [e.g., optic tract in the lateral geniculate nucleus (LGN)]. Consistent with the lack of labeling in the auditory and olfactory nerves, neither the cochlear nucleus (auditory) nor the olfactory bulb contained any labeled processes.

In addition to spinal roots and cranial nerves and their respective tracts, only a small number of well-defined white matter tracts were labeled with the $57 \mathrm{kDa}$ NIFP antiserum. Most of the long tracts, peduncles, and commissures, identifiable with the NFT antibody $15 \mathrm{Gl}$, were unlabeled with $57 \mathrm{kDa}$ NIFP antiserum. In contrast, prominent $57 \mathrm{kDa}$ NIFP labeling was present in certain pathways having a high proportion of very thin axons. Such pathways included the collateral visual pathway to the superior colliculus (Fig. 4C), the olivocerebellar bundles, the inferior cerebellar peduncle (ICP), and the uncinate (Fig. 5). In the cerebellum, the heaviest array of $57 \mathrm{kDa}$ NIFPcontaining fibers was present adjacent to the deep cerebellar nuclei and in the vermal white matter. There was a posterior to anterior decrease in the density of labeled fibers in cerebellar white matter. In particular, labeling was very sparse in the subcortical white matter of the anterolateral lobules (Fig. 5). The ventral spinocerebellar tract, medial longitudinal fasciculus, and rubrospinal tract were the only tracts besides cranial nerve components to contain labeled large-caliber axons.

In addition to their presence in well-defined white matter 
Table 1. $57 \mathrm{kDa}$ NIFP in gray matter

\begin{tabular}{|c|c|c|c|}
\hline \multirow[b]{2}{*}{ CNS region } & \multirow[b]{2}{*}{ Cytokarya } & \multicolumn{2}{|c|}{ Labeled processes ${ }^{a}$} \\
\hline & & Thin & Thick \\
\hline \multicolumn{4}{|l|}{ Motor nuclei } \\
\hline VHSpC, VII, V, III & Few & - & $\mathbf{E}$ \\
\hline XII, VI, IV & - & - & $\mathrm{E}$ \\
\hline \multicolumn{4}{|l|}{ Autonomic motor } \\
\hline IML, DVg, Amb, EW, ? Salivatory & Many & ++ & - \\
\hline \multicolumn{4}{|l|}{ Sensory nuclei } \\
\hline DRG, GnV, MesV, RetGn & Many & - & $\mathrm{E}$ \\
\hline DH1, LG (afferents to deep layers) & - & ++ & - \\
\hline DH2-3, Sol, MVst, SpVst & - & + & - \\
\hline SpV, PrV, Cu, SVst, LVst & - & - & $\mathrm{X}$ \\
\hline $\mathrm{Clk}, \mathrm{Gr}, \mathrm{ECu}$, thalamus & - & - & - \\
\hline VC, SO, TzB, LL, IC, MG, SC (gray) & - & - & - \\
\hline \multicolumn{4}{|l|}{ Precerebellar/cerebellar nuclei } \\
\hline $\mathrm{IOb}, \mathrm{PGe}$ & Many & + & - \\
\hline GCL (vermis) & - & + & - \\
\hline IO (all other), Pn, DCN, GCL (lat) & - & - & - \\
\hline RN (midline decussation) & - & - & $\mathrm{X}$ \\
\hline \multicolumn{4}{|l|}{ Brain stem reticular formation } \\
\hline \multicolumn{4}{|l|}{ Cholinergic } \\
\hline LDTg, SPTg, PPTg & Many & ++ & - \\
\hline \multicolumn{4}{|l|}{ Catecholaminergic } \\
\hline $\mathrm{RVL} / \mathrm{C} 1, \mathrm{C} 3, \mathrm{~A} 1, \mathrm{~A} 4, \mathrm{~A} 5, \mathrm{~A} 7, \mathrm{LC}$ & - & - & - \\
\hline \multicolumn{4}{|l|}{ Medulla and pons } \\
\hline MdV, LPGi, PnC, MnR & - & ++ & - \\
\hline LRt, ROb, RMg, RPn, VLTg, PnO, PMnRt & - & + & - \\
\hline $\mathrm{RPa}, \mathrm{DMTg}$ & - & - & $\mathrm{X}$ \\
\hline PrH, MdD, DTg, Gi, DPGi, PCRt, PB, KF & - & - & - \\
\hline \multicolumn{4}{|l|}{ Diencephalon/midbrain } \\
\hline TMC, CMC, PCMC & Many & ++ & - \\
\hline CTgT, DpMe, VTA/SuM, LM & - & ++ & - \\
\hline region medial to $\mathrm{MG}, \mathrm{PP}, \mathrm{PIL}$ & - & ++ & - \\
\hline CnF, PAG, RtTh, SNC, LH & - & + & - \\
\hline PTA & - & + & $\mathrm{X}$ \\
\hline MiTg, SNR, thalamus (except LG, RtTh) & - & - & - \\
\hline IPN, hypothalamus (all other regions) & - & - & - \\
\hline \multicolumn{4}{|l|}{ Telencephalon } \\
\hline Cerebral cortex & Few & - & - \\
\hline ZI, B, lat preoptic area & - & + & - \\
\hline $\mathrm{SA}, \mathrm{CPu}, \mathrm{GP}, \mathrm{VP}, \mathrm{Amy}, \mathrm{Hp}$ & - & - & - \\
\hline
\end{tabular}

$\bar{a}+=$ sparse array of labeled processes; $++=$ dense array of labeled processes; $E=$ labeled axons exiting nucleus of origin; $\mathbf{X}=$ thick axons crossing nuclear region. Anatomic abbreviations are defined in the Key to Figure 1.

tracts, thin fibers were abundant in brain stem, particularly in well-delimited portions of the reticular formation (RF), and in those nuclei having neuronal cytoplasmic staining (Table 1). Cerebral cortex, dorsal hypothalamus, anterior and lateral cerebellum, and the parvocellular RF of caudal pons and medulla contained only occasional thin fibers. Regions of the brain notable for the absence of immunodetectable $57 \mathrm{kDa}$ NIFP included the olfactory bulb, basal ganglia, hippocampus, amygdala, habenula, all nuclei of the auditory pathway including the inferior colliculus, and most of thalamus except for reticular thalamus and axons entering the LGN.

\section{Discussion}

The results of this study indicate that the $57 \mathrm{kDa}$ NIFP has a prominent CNS presence largely confined to the brain stem and spinal cord. In contrast to the widespread distribution of the NFT proteins, the distribution of the $57 \mathrm{kDA}$ NIFP is restricted to specific neuronal groups and axonal pathways. $57 \mathrm{kDa}$ NIFP antiserum-labeling of CNS axons falls into 3 main categories. These include 1) cranial nerves and their tracts, 2) a specific subset of vestibulocerebellar pathways, and 3) a subset of brain stem RF. The immunofluorescence and in situ hybridization data indicate that the neuronal groups containing $57 \mathrm{kDa}$ NIFP fall into 5 functional categories: 1) Primary sensory ganglia, 2) skeletal and autonomic motor nuclei, 3) brain stem cholinergic nuclei, 4) nuclei thought to modulate vestibular information, the caudal medial accessory nucleus (CMAO) and the paragenual nucleus (efferents to the vestibular labyrinth), and 5) the caudal magnocellular nuclear groups of the hypothalamus. Leonard et al. (1988) additionally identified mRNA for this 


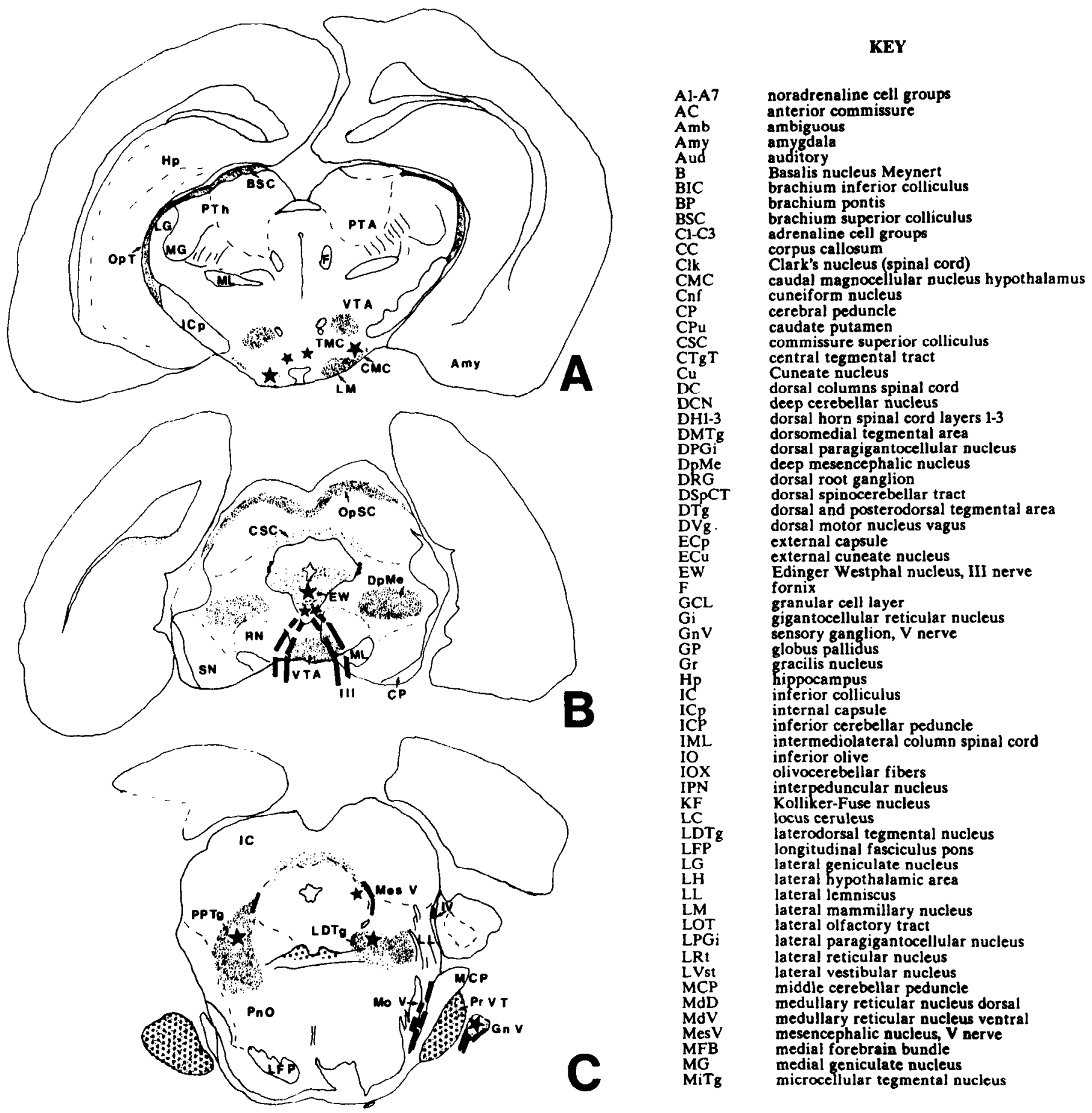

Figure 1. Overview of the $57 \mathrm{kDa}$ NIFP in the CNS. Labeled areas indicate the distribution of the $57 \mathrm{kDa}$ NIFP by immunofluorescence in the telencephalon-diencephalon $(A)$, midbrain $(B)$, rostral pons $(C)$, caudal pons $(D)$, rostral medulla $(E)$, mid-medulla $(F)$ and spinal cord $(G)$. Sections rostral to $A$ contain label only within optic tract, medial forebrain bundle, and cingulum. Fine continuous lines indicate anatomic and gray-white matter boundaries. Fine dashed lines indicate gray matter divisions, e.g., the granule cell-molecular layer division in the cerebellum. All sections are coronal and slightly asymmetric; the left side is approximately $1 \mathrm{~mm}$ rostral to the right. Anatomic abbreviations are defined in the Key.

protein in neurons of vestibular and deep cerebellar nuclei.

Among the CNS nuclei described above, there is a subset in which the $57 \mathrm{kDa}$ NIFP antiserum identifies antigen in the axonal process but not within the cytokaryon of most of the neurons. These include the somatic motor cranial nerve nuclei, the red nucleus, the medial deep cerebellar nucleus, and the ventral horn nuclei. The varied ability for polyclonal and mono- clonal antibodies to recognize the NFT proteins in the cytokaryon versus axonal process (Shaw et al., 1981; Goldstein et al., 1983; Sternberger and Sternberger, 1983) or among neurons of the same type (Trojanowski et al., 1985) has bcen well described and has usually been attributed to post-translational modifications of the IF causing structural changes that either reveal or block epitopes (Sternberger and Sternberger, 1983; 

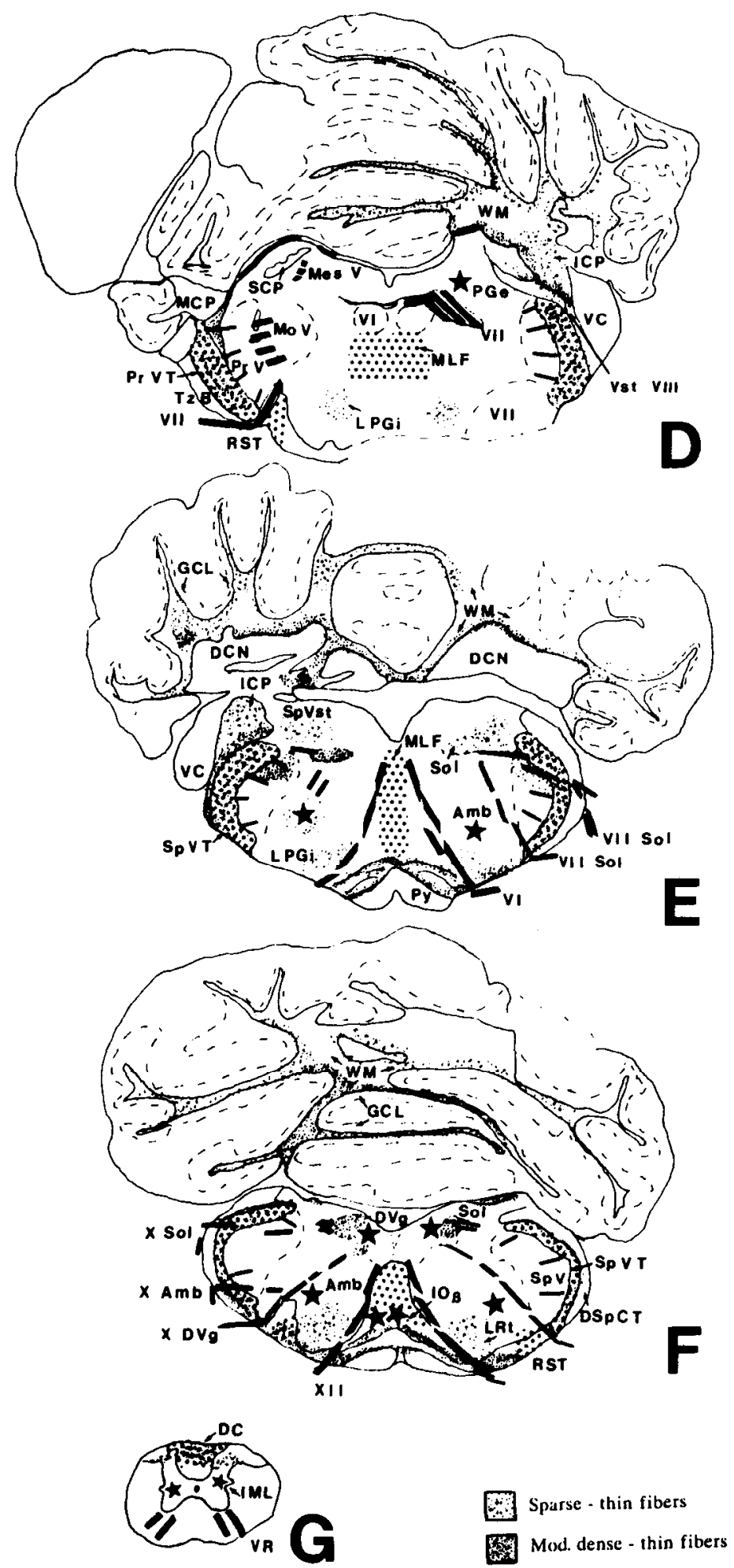

Figure 1. Continued.

Carden et al., 1985). Although we do not know the factor(s) responsible for masked $57 \mathrm{kDa}$ NIFP epitopes in the cell bodies of some neurons, the correlative data obtained by in situ hybridization have allowed an accurate examination of $57 \mathrm{kDa}$ NIFP distribution (Leonard et al., 1988; Parysek et al., 1988; present study). The data suggest that the $57 \mathrm{kDa}$ NIFP indeed has a restricted distribution and that the findings are not simply

\section{KEY (Continued)}

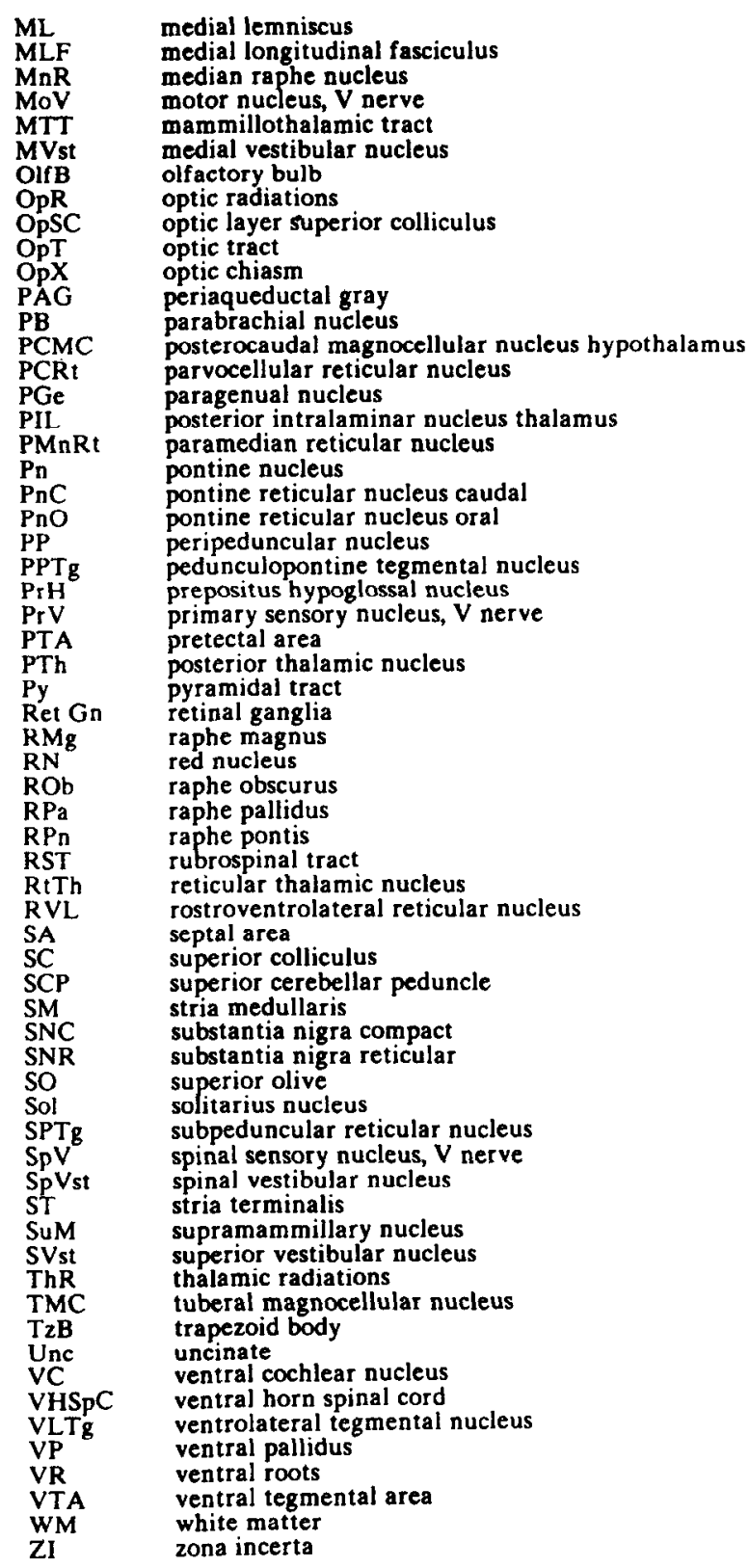

E:? Thick axons cross-section

Nerves or tracts - thick axom
if Nuclei with babeled neurons because of restricted antigen recognition by the particular antiserum used in this study.

The recently reported immunolocalization study for periphcrin indicates that it, too, has a highly restricted CNS distribution (Escurat et al., 1988). Like the $57 \mathrm{kDa}$ NIFP, peripherin is present in sensory ganglia including retinal ganglion cells and in spinal motor neurons. In contrast to the $57 \mathrm{kDa}$ NIFP, 

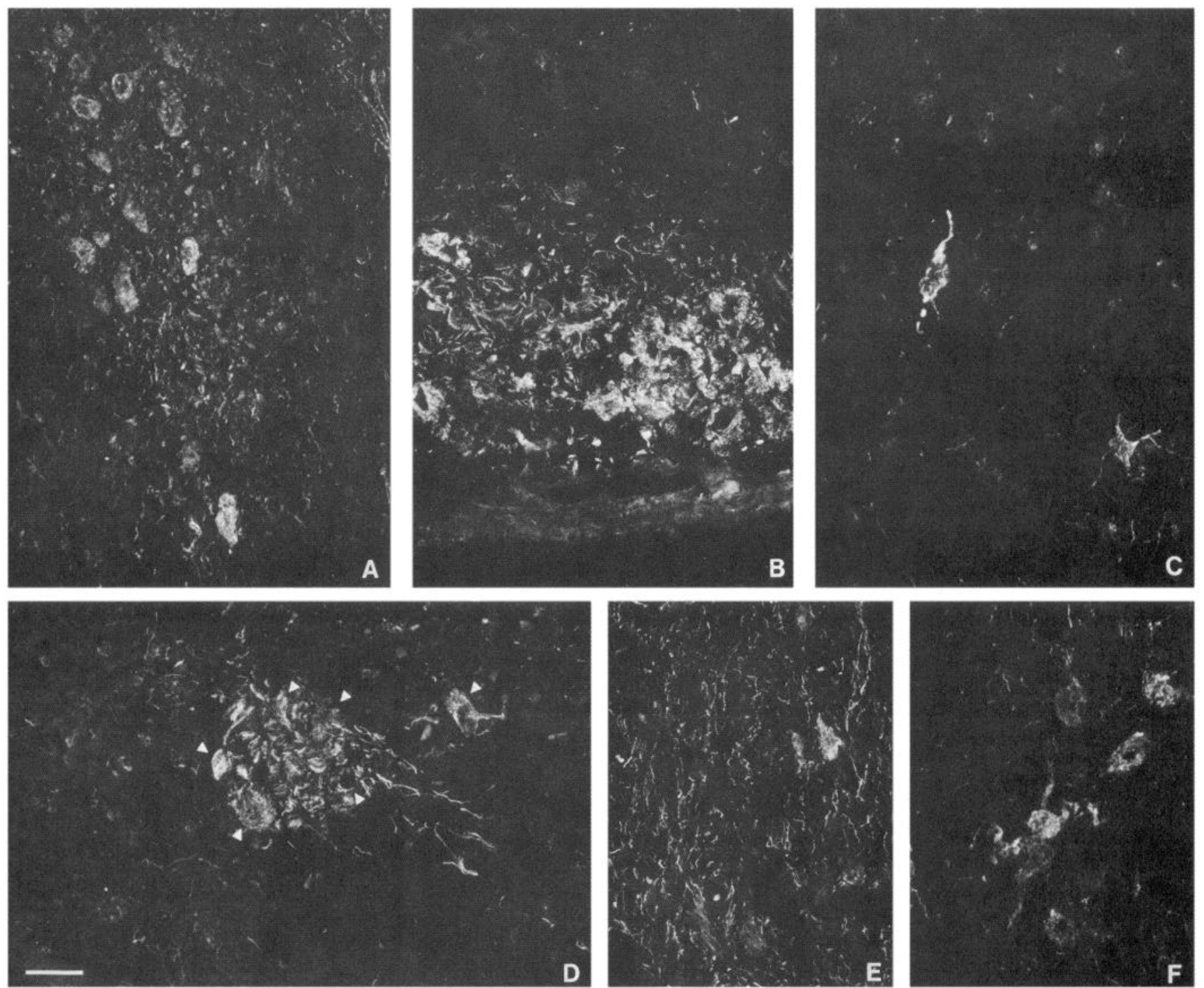

Figure 2. Distribution of the $57 \mathrm{kDa}$ NIFP in gray matter. The $57 \mathrm{kDa}$ NIFP antiserum labels cytokarya and thin processes of a select group of CNS nuclei including the dorsal motor nucleus of X $(A)$, the caudal magnocellular nucleus of the hypothalamus $(B)$, and the intermediolateral cell column of the thoracic spinal cord (filled triangles indicate cell bodies) $(D)$. Rare labeled cytokarya are present within very sparsely labeled neuropil in the cerebral cortex $(C)$. In contrast, fibrillary label is present in the cytokarya of numerous neurons that are widely scattered among a moderately dense array of labeled processes $(E)$ in a region that extends diagonally within the rostral pons from the rostral end of the PPTg $(F)$ just caudal to the substantia nigra to its more dorsal caudal end and then extends beneath the SCP to include the area of the LDTg in the periaqueductal gray matter (see Fig. 1B). Scale bar, $25 \mu \mathrm{m}$.

peripherin was not recognized in the brain stem but was present in olfactory nerves and receptor neurons where other neuronal IF proteins previously were shown to be absent (Schwob et al., 1986). Thus, either peripherin and the $57 \mathrm{kDa}$ NIFP are similar but not identical NIFP or the antisera utilized for the respective immunolocalization studies have different specificities for the same protein.

On the basis of the data available prior to this study, hypotheses have been formed that correlate the unique distribution of $57 \mathrm{kDa}$ NIFP with neuronal function. The suggestion that the $57 \mathrm{kDa}$ NIFP has some function specific to first-order axons (Parysek and Goldman, 1988) is supported by the finding that none of the second-order somatosensory neurons or their axons contains the $57 \mathrm{kDa}$ NIFP. Another hypothesis advanced was that the $57 \mathrm{kDa}$ NIFP provides a structural stabilizing function for very long axons which cross from CNS to PNS or vice versa (Escurat et al., 1988; Leonard et al., 1988). The absence of the $57 \mathrm{kDa}$ NIFP from certain CNS long tracts such as the corticospinal tract and from the auditory nerve and pathway indicates that the presence of the protein is not essential to stabilize all long axons or all nerves crossing from PNS to CNS nor is it present in all first-order sensory axons. The prominent presence of the $57 \mathrm{kDa}$ NIFP in 2nd-order visual and proprioceptivecerebellar axons as well as certain RF pathways arising within the CNS indicates that this NIFP is not confined to long-tract axons or to first-order axons. Thus, the additional data of this study corroborate prior observations but also provide findings that do not support past hypotheses.

The functional and anatomic characteristics of the small subset of nuclear groups containing fibrillary labeling suggest 2 dif- 

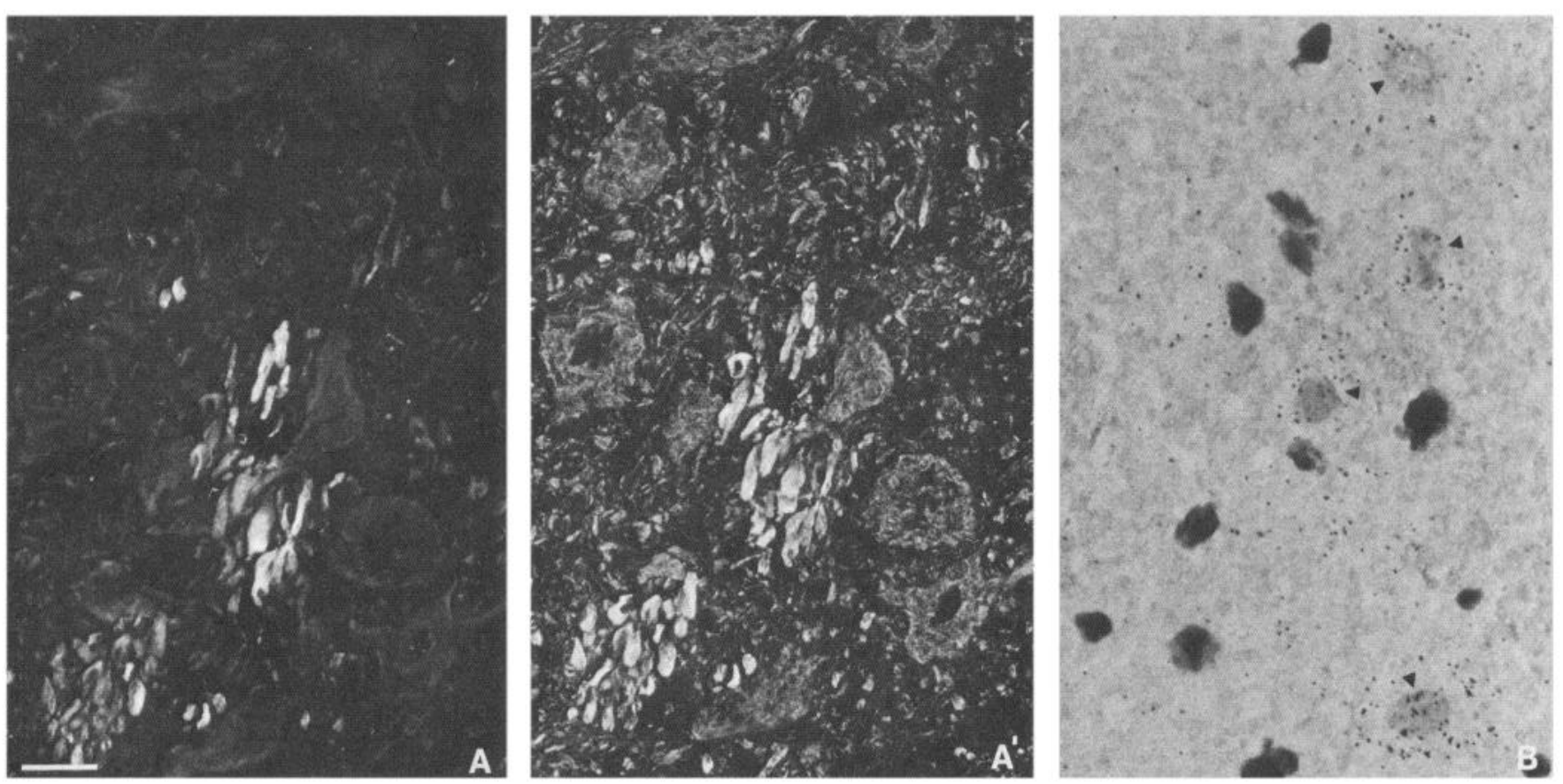

Figure 3. Distribution of immunodetectable $57 \mathrm{kDa}$ NIFP and $57 \mathrm{kDa}$ NIFP mRNA in motor nuclei. Double-label immunofluorescence of a section of the VII nucleus shows labeled large fibers and weak or no labeling of motor neurons with $57 \mathrm{kDa}$ NIFP antiserum $(A)$. The large axons (presumptive axons of VII) and motor neurons are labeled with $15 \mathrm{G} 1\left(A^{\prime}\right)$. In situ hybridization of a $57 \mathrm{kDa}$ NIFP-specific cDNA to a similar but nonadjacent section reveals the presence of the $57 \mathrm{kDa}$ NIFP mRNA in these cells. Filled triangles identify nuclei of labeled neurons in $B$. Scale bar, $25 \mu \mathrm{m}$.

Table 2. $57 \mathrm{kDa}$ NIFP in white matter

\begin{tabular}{|c|c|c|c|}
\hline \multirow[b]{2}{*}{ CNS region } & \multicolumn{3}{|c|}{ Axon caliber $^{a}$} \\
\hline & Thin & Moderate & Thick \\
\hline \multicolumn{4}{|l|}{ Motor roots and nerves } \\
\hline III, IV, V, VI, VII, ventral roots & - & - & ++ \\
\hline IX, X (exit ventrally) & ++ & + & - \\
\hline \multicolumn{4}{|l|}{ Sensory nerves and tracts } \\
\hline II, OpX, OpT & + & ++ & - \\
\hline BSC, CSC, OpSC & ++ & - & - \\
\hline MesVT & + & - & ++ \\
\hline DC, SpVT, PrVT & + & ++ & + \\
\hline Vestibular VIII & + & - & - \\
\hline SolT, IX, X (exit laterally) & ++ & + & - \\
\hline Aud VIII, TzB, LL, BIC, ML, ThR & - & - & - \\
\hline OpR, OlfB, LOT & - & - & - \\
\hline \multicolumn{4}{|l|}{ Motor/cerebellar tracts and peduncles } \\
\hline VSpCT, MLF, RST & - & ++ & - \\
\hline IOX, Unc, ICP (lacy pattern laterally) & ++ & - & - \\
\hline DSpCT, MCP, SCP, BP, Py, LFP, CP & - & - & - \\
\hline \multicolumn{4}{|l|}{ Cerebellar white matter } \\
\hline Vermis, amiculum DCN & $+/++$ & - & - \\
\hline Central, lateral folia & $+1-$ & - & - \\
\hline \multicolumn{4}{|l|}{ Telencephalon/diencephalon } \\
\hline Cingulum, ST, MFB & + & - & - \\
\hline ECp, CC, ICp, AC, F, MTT, SM & - & - & - \\
\hline
\end{tabular}

$\overline{a+=}$ sparse array of labeled axons; $++=$ dense array of labeled axons. Anatomic abbreviations are defined in the Key to Figure 1 . 

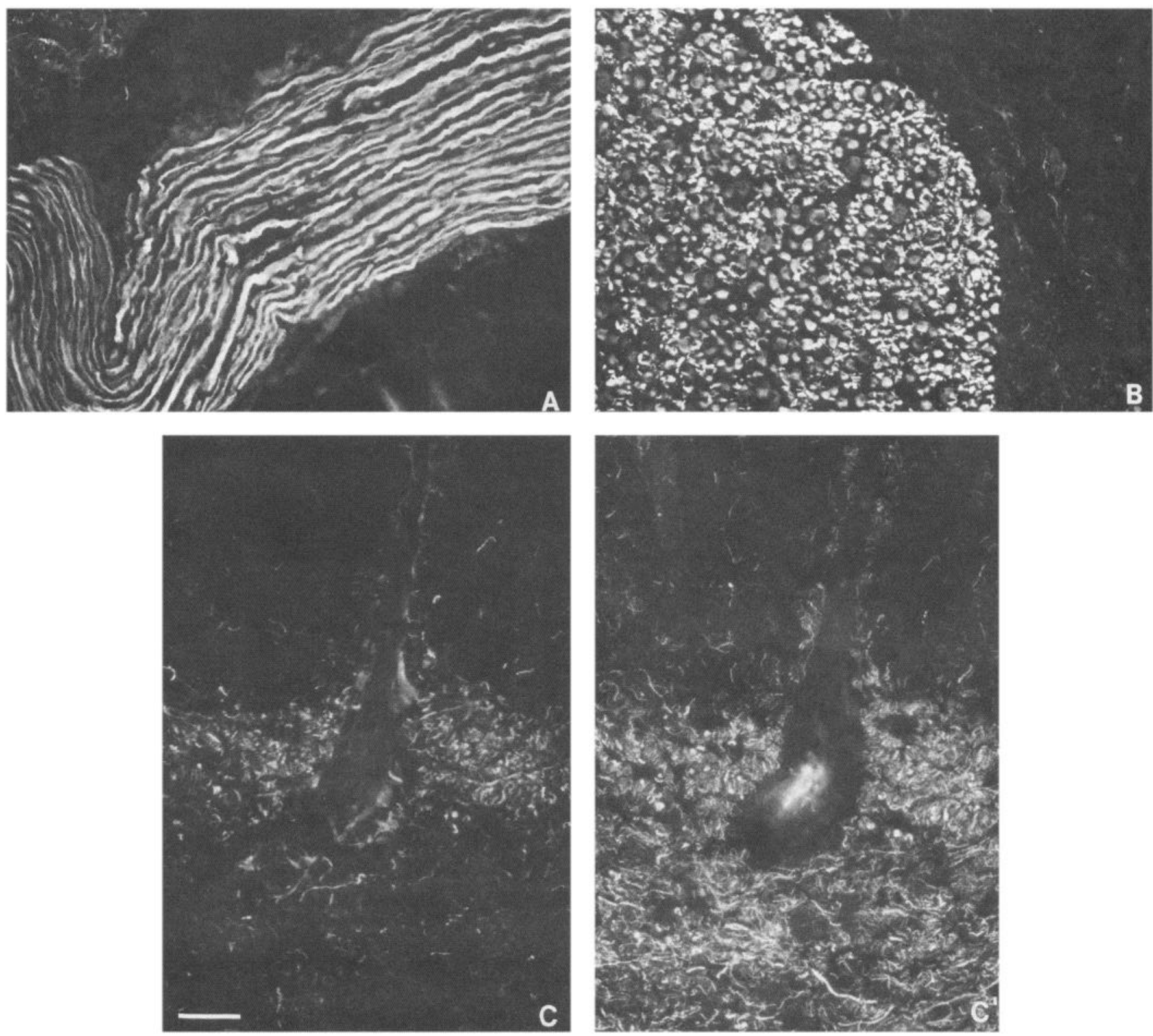

Figure 4. Labeling patterns of cranial nerves and tracts with $57 \mathrm{kDa}$ NIFP antiserum. The XII cranial nerve in the leptomeningeal space $(A)$, spinal tract of V $(B)$, and superior colliculus $(C)$ are labeled with $57 \mathrm{kDa}$ NIFP antiserum; $C$ is double-labeled with $15 \mathrm{Gl}\left(C^{\prime}\right)$. The labeling patterns shown in $A$ are typical of large axons in motor nerves and roots; those shown in $B$ are consistently seen in sensory tracts, nerves, and roots; and those shown in $C$ typify areas of dense labeling of thin fibers. Comparison of $C$ and $C^{\prime}$ reveals the restricted labeling of a single layer, the optic layer, with $57 \mathrm{kDa}$ NIFP antiserum. Scale bar, $25 \mu \mathrm{m}$.

ferent and probably independent organizing principles for CNS utilization of the $57 \mathrm{kDa}$ NIFP. First, there appears to be a striking correlation between the distribution of neurons containing $57 \mathrm{kDa}$ NIFP and those containing the enzyme CAT in the brain stem and spinal cord. The largest group of $57 \mathrm{kDa}$ NIFP antiserum-positive neurons includes the autonomic motor neurons, preganglionic sympathetic neurons, and numerous neurons within the region of the PPTg and LDTg. These nuclei as well as the brain stem and spinal cord motor nuclei have in common many densely packed CAT-containing neurons (Sofroniew et al., 1985). The correlation between the presence of 57 $\mathrm{kDa}$ NIFP and CAT is not complete since the major cholinergic regions in the telencephalon contain extremely sparse processes labeled by the $57 \mathrm{kDa}$ NIFP antiserum; however, the degree of correlation is intriguing.

A potential relationship between the $57 \mathrm{kDa}$ NIFP and cholinergic transmitter function is supported by the physiologic characteristics of $\mathrm{PC} 12$ cells. PC12 cells have been shown to contain CAT and to synthesize, store, and release acetylcholine (Schubert et al., 1977) in addition to norepinephrine and dopamine (Greene and Rein, 1977). Induction of neuronal differentiation in PC12 cells by NGF results in decreased catecholamine content, decreased numbers of catecholaminergic-type large granules, and an increase in the cholinergic-type agranular vesicles (Tischler and Greene, 1978). Furthermore, while the correspondence between $57 \mathrm{kDa}$ NIFP-positive regions and 

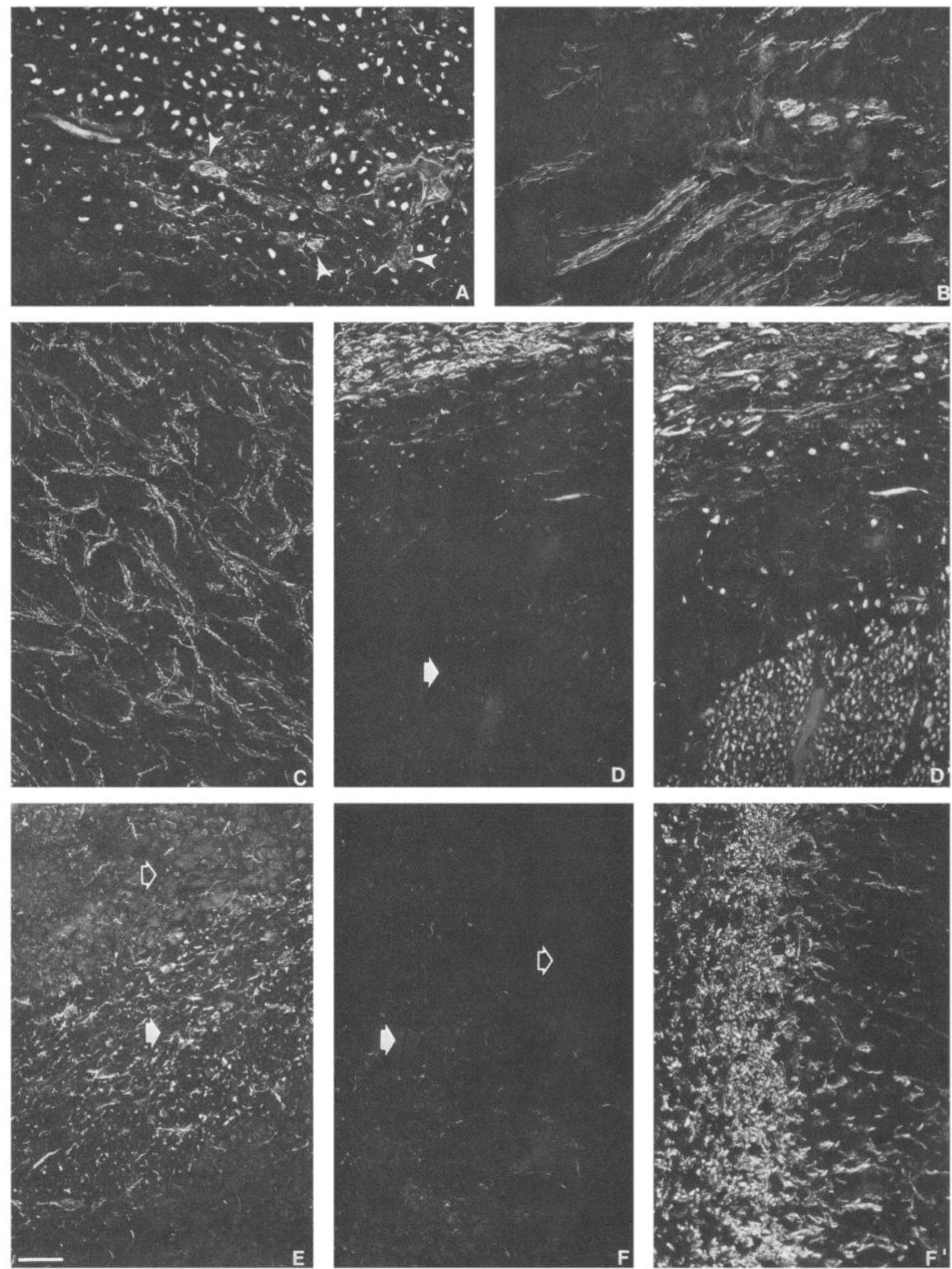

Figure 5. $57 \mathrm{kDa}$ NIFP distribution in olivovestibulocerebellar pathways. $57 \mathrm{kDa}$ NIFP antiserum labels the cytokarya (arrowheads) in the $\beta$-subnucleus of the inferior olive, seen among labeled thick axons of the MLF $(A)$. Labeled tracts of the olivovestibulocerebellar system include olivocerebellar fibers $(B)$, a subpopulation of axons in the ICP $(C)$, and the uncinate tract $(D)$. The SCP, carrying cerebellar efferents to the thalamus, is unlabeled $(D)$. A moderately dense array of cerebellar subcortical fibers is labeled in the posterior vermis $(E)$ in contrast to the very sparse labeling present in the anterolateral cerebellum $(F)$. Closed arrows indicate left edge of the SCP in $D$ and the white matter in $E$ and $F$. Open arrows indicate the granule cell layer in $E$ and $F$. Double-labeling of $D$ and $F$ with $15 \mathrm{G} 1$ reveals, respectively, the SCP $\left(D^{\prime}\right)$ and the subcortical white matter in the anterolateral cerebellum $\left(F^{\prime}\right)$. Scale bar, $25 \mu \mathrm{m}$. 
CAT-positive regions is high, there is a notable lack of correspondence between the distribution of $57 \mathrm{kDa}$ NIFP and neuron systems defined by dopamine or norepinephrine (Lindvall and Bjorklund, 1983), Substance P and enkephalin (Cuello et al., 1985), neuropeptide Y (Chronwall et al., 1985), or serotonin (Tork, 1985).

The second possible organizing principle of $57 \mathrm{kDa}$ NIFP distribution reflects observations that a subset of prominently labeled brain stem and cerebellar regions form an interconnected olivovestibulocerebellar circuit (Table 2). Numerous neuronal cytokarya in the subnucleus $\beta$ of the CMAO were labeled by the $57 \mathrm{kDa}$ NIFP antiserum. In situ hybridization indicated that $57 \mathrm{kDa}$ NIFP message is present in several subnuclei of the CMAO in addition to the $\mathrm{IO} \beta$. Neurons of the CMAO provide the afferent climbing fibers to the vestibular zone (medial zone A) of the cerebellar vermis (Brodal, 1980). The vermal medial zone $A$ receives vestibular afferents and projects back to the deep medial cerebellar nuclei and to brain stem vestibular nuclei (these nuclei were labeled by clone 73; Leonard et al., 1988) (Ito, 1980; Walberg, 1980). The present study shows that, in addition to the more posterior regions of the cerebellar white matter, the portions of the vestibulocerebellar system labeled by $57 \mathrm{kDa}$ NIFP antiserum included the uncinate tract and the medial ICP. The uncinate tract carries efferents from the medial cerebellar nucleus to the vestibular nuclei (Carpenter and Batton, 1982). Anatomic studies have indicated that the thin axons of the medial ICP are most likely olivocerebellar fibers originating in the IO (Szentagothai-Schimert, 1942; Voogd and Bigare, 1980). In contrast, the superior and middle cerebellar peduncles carrying telencephalic cerebellar afferent and efferent fibers were unlabeled by the $57 \mathrm{kDa}$ NIFP antiserum. Thus, for both the CNS cholinergic and motor control systems, antiserum to the $57 \mathrm{kDa}$ NIFP apparently labels only the brain stem and spinal cord components.

The molecular function of NIF (and IF in general) remains elusive. The structure of these filaments and their demonstrated molecular linkages with other filaments and cytoplasmic organelles historically has been interpreted in the context of a cytoskeletal function (for review, see Lazarides, 1982; Traub, 1985). This view is reflected in the hypothesis that neurofilaments are a major determinant of axonal caliber (Hoffman et al., 1987). This demonstration of a select CNS NIFP distribution potentially related to behavioral-functional or to neurotransmitterrelated anatomic organization suggests that IFs may have other roles in addition to their structural role in neurons. The $57 \mathrm{kDa}$ NIFP may be only one of many possible systems-specific NIFs. The identification of such systems would not only contribute to the understanding of CNS organization on a molecular level but also to the understanding of the function of IFs.

\section{References}

Brodal, A. (1980) Olivocerebellocortical projection in the cat as determined with the method of retrograde axonal transport of horseradish peroxidase. 2 . Topographical pattern in relation to the longitudinal subdivision of the cerebellum. In The Inferior Olivary Nucleus: Anatomy and Physiology, J. Courville, C. de Montigny, and Y. Lamarre, eds., pp. 187-232, Raven, New York.

Brown, B. A., R. A. Nixon, P. Strocchi, and C. A. Marotta (1981) Characterization and comparison of neurofilament proteins from rat and mouse CNS. J. Neurochem. 36: 143-153.

Carden, M. J., W. W. Schlaepfer, and V. M.-Y. Lee (1985) The structure, biochemical properties, and immunogenicity of neurofilament peripheral regions are determined by phosphorylation state. J. Biol. Chcm. 260: 9805-9817.
Carpenter, M. B., and R. R. Batton III (1982) Connections of the fastigial nucleus in the cat and monkey. In The Cerebellum-New Vistas. Exp. Brain Res. (suppl. 6), S. L. Palay and V. Chan-Palay, eds., pp. 250-295, Springer-Verlag, Berlin.

Chronwall, B. M., D. A. DiMaggio, V. J. Massari, V. M. Pickel, D. A. Ruggiero, and T. L. O'Donohue (1985) The anatomy of neuropeptide-Y-containing neurons in rat brain. Neuroscience 15: 1159-1181.

Cuello, A. C., J. V. Priestley, and G. Paxinos (1985) Substance P and enkephalin containing pathways. In The Rat Nervous System, Vol. I, G. Paxinos, ed., pp. 441-469, Academic, Sydney.

Czosnek, H., and D. Soifer (1980) Comparison of the proteins of 10 $\mathrm{nm}$ filaments from rabbit sciatic nerve and spinal cord by electrophoresis in two dimensions. FEBS Lett. 117: 175-178.

Escurat, M., M. Gumpel, F. Lachapelle, F. Gros, and M.-M. Portier (1988) Expression comparée de deux protéines de filaments intermédiaires, la périphérine et la protéine de neurofilament $68 \mathrm{kDa}$, au cours du développement embryonnaire du rat. C. R. Acad. Sci. Paris, t. 306, Serie III, pp. 446-456.

Goldstein, M. E., L. A. Sternberger, and N. H. Sternberger (1983) Microheterogeneity ("neurotypy") of neurofilament proteins. Proc. Natl. Acad. Sci. USA 80: 3101-3105.

Greene, L. A., and G. Rein (1977) Release, storage and uptake of catecholamines by a clonal cell line of nerve growth factor (NGF) responsive pheochromocytoma cells. Brain Res. 129: 247-263.

Hoffman, P. N., D. W. Cleveland, J. W. Griffin, P. W. Landes, N. J. Cowan, and D. L. Price (1987) Neurofilament gene expression: A major determinant of axonal caliber. Proc. Natl. Acad. Sci. USA 84: 3472-3476.

Ito, M. (1980) Roles of the inferior olive in the cerebellar control of vestibular functions. In The Inferior Olivary Nucleus: Anatomy and Physiology, J. Courville, C. de Montigny, and Y. Lamarre, eds., pp. 367-377, Raven, New York.

Lazarides, E. (1982) Intermediate filaments: A chemically heterogenous, developmentally regulated class of proteins. Annu. Rev. Biochem. 51:219-250.

Leonard, D. G. B., J. D. Gorham, P. Cole, L. A. Greene, and E. B. Ziff (1988) A nerve growth factor-regulated messenger RNA encodes a new intermediate filament protein. J. Cell Biol. 106: 181-193.

Liem, R. K. H., S.-H. Yen, G. D. Salomon, and M. L. Shelanski (1978) Intermediate filaments in nervous tissues. J. Cell Biol. 79: 637-645.

Lindvall, O., and A. Bjorklund (1983) Dopamine- and norepinephrine-containing neuron system: Their anatomy in the rat brain. In Chemical Neuroanatomy, P. C. Emson, ed., pp. 229-255, Raven, New York.

Luna, L. G. (1968) Manual of Histologic Staining Methods of the Armed Forces Institute of Pathology, pp. 36-39, 103-104, McGrawHill, New York.

Parysek, L. M., and R. D. Goldman (1987) Characterization of intermediate filaments in PC12 cells. J. Neurosci. 7: 781-791.

Parysek, L. M., and R. D. Goldman (1988) Distribution of a novel $57 \mathrm{kDa}$ intermediate filament (IF) protein in the nervous system. $\mathrm{J}$. Neurosci. 8: 555-563.

Parysek, L. M., R. L. Chisholm, C. A. Ley, and R. D. Goldman (1988) A type III intermediate filament gene is expressed in mature neurons. Neuron 1:395-401.

Paxinos, G., and C. Watson (1986) The Rat Brain in Stereotaxic Coordinates, 2nd ed., Academic, Sydney.

Portier, M.-M., B. Croizat, and F. Gros (1982) A sequence of changes in cytoskeletal components during neuroblastoma differentiation. FEBS Lett. 146: 283-288.

Portier, M.-M., P. Brachet, B. Croizat, and F. Gros (1984a) Regulation of peripherin in mouse neuroblastoma and rat $\mathrm{PC} 12$ pheochromocytoma cell lines. Dev. Neurosci. 6: 215-226.

Portier, M.-M., B. de Nechaud, and F. Gros (1984b) Peripherin, a new member of the intermediate filament protein family. Dev. Neurosci. 6: 335-344.

Schlaepfer, W. W., and L. A. Freeman (1978) Neurofilament proteins of rat peripheral nerve and spinal cord. J. Cell Biol. 78: 653-662.

Schubert, D., S. Heinemann, and Y. Kidokoro (1977) Cholinergic metabolism and synapse formation by a rat nerve cell line. Proc. Natl. Acad. Sci. USA 74: 2579-2583.

Schwob, J. E., N. B. Farber, and D. I. Gottlieb (1986) Neurons of the olfactory epithelium in adult rats contain vimentin. J. Neurosci. 6 : 208-217.

Shaw, G., M. Osborn, and K. Weber (1981) An immunofluorescence 
microscopical study of the neurofilament triplet proteins, vimentin and glial fibrillary acidic protein within the adult rat brain. Eur. J. Cell Biol. 26: 68-82.

Sofroniew, M. V., P. E. Campbell, A. C. Cuello, and F. Eckenstein (1985) Central cholincrgic ncurons visualized by immunohistochemical detection of choline acetyltransferase. In The Rat Nervous System, Vol. I, G. Paxinos, ed., pp. 471-485, Academic, Sydney.

Steinert, P. W., and D. R. Roop (1988) Molecular and cellular biology of intermediate filaments. Annu. Rev. Biochem. 57: 593-625.

Sternberger, L. A., and N. H. Sternberger (1983) Monoclonal antibodies distinguish phosphorylated and nonphosphorylated forms of neurofilaments in situ. Proc. Natl. Acad. Sci. USA 80: 6126-6130.

Szentagothai-Schimert, J. (1942) Die Bedeutung des Faserkalibers und der Markscheidendicke im Zentralnervensystem. In Zeitschrift für Anatomie und Entwicklungsgeschichte, C. Elze, ed., pp. 201-223, Springer-Verlag, Berlin.

Tischler, A. S., and L. A. Greene (1978) Morphologic and cytochemical properties of a clonal line of rat adrenal pheochromocytoma cells which respond to nerve growth factor. Lab. Invest. 39: 77-88.

Tork, I. (1985) Raphe nuclei and serotonin containing systems. In The Rat Nervous System, Vol. II, G. Paxinos, ed., pp. 43-78, Academic, Sydney.

Traub, P. (1985) Functional theories. In Intermediate Filaments, P. Traub, ed., pp. 170-193, Springer-Verlag, Berlin.

Trojanowski, J. Q., M. A. Obrocka, and V. M.-Y. Lee (1985) Distri- bution of neurofilament subunits in neurons and neuronal processes: Immunohistochemical studies of bovine cerebellum with subunitspecific monoclonal antibodies. J. Histochem. Cytochem. 33: 557563.

Trojanowski, J. Q., N. Walkenstein, and V. M.-Y. Lee (1986) Expression of neurofilament subunits in neurons of the central and peripheral nervous system: An immunohistochemical study with monoclonal antibodies. J. Neurosci. 6: 650-660.

Voogd, J., and F. Bigare (1980) Topographical distribution of olivary and cortico nuclear fibers in the cerebellum: A review. In The Inferior Olivary Nucleus: Anatomy and Physiology, J. Courville, C. de Montigny, and Y. Lamarre, eds., pp. 207-230, Raven, New York.

Walberg, F. (1980) Olivocerebellocortical projection in the cat as determined with the method of retrograde axonal transport of horseradish peroxidase 1 . Topographical pattern. In Inferior Olivary $\mathrm{Nu}$ cleus: Anatomy and Physiology, J. Courville, C. de Montigny, and Y. Lamarre, eds., pp. 169-186, Raven, New York.

Yen, S.-H., and K. L. Fields (1981) Antibodies to neurofilament, glial filament, and fibroblast intermediate filament proteins bind to different cell types of the nervous system. J. Cell Biol. 88: 115-126.

Zackroff, R. V., W. W. Idler, P. M. Steinert, and R. D. Goldman (1982) In vitro reconstitution of intermediate filaments from mammalian neurofilament triplet polypeptides. Proc. Natl. Acad. Sci. USA 79: 754-757. 